2010

\title{
Good and Bad, I Defined These Terms, Quite Clear No Doubt Somehow: Neuroimaging and Competency to be Executed after Panetti
}

Michael L. Perlin

New York Law School, michael.perlin@nyls.edu

Follow this and additional works at: https://digitalcommons.nyls.edu/fac_articles_chapters

Part of the Law and Psychology Commons

\section{Recommended Citation}

Perlin, Michael L., "Good and Bad, I Defined These Terms, Quite Clear No Doubt Somehow: Neuroimaging and Competency to be Executed after Panetti" (2010). Articles \& Chapters. 1201.

https://digitalcommons.nyls.edu/fac_articles_chapters/1201 
Behavioral Sciences and the Law

Behav. Sci. Law 28: 671-689 (2010)

Published online in Wiley Online Library

(wileyonlinelibrary.com) DOI: $10.1002 / \mathrm{bsl} .955$

\title{
"Good and Bad, I Defined These Terms, Quite Clear No Doubt Somehow': Neuroimaging and Competency to be Executed after Panetti
}

\author{
Michael L. Perlin, J.D.* ${ }^{* \dagger}$
}

There has been little consideration, in either the caselaw or the scholarly literature, of the potential impact of neuroimaging on cases assessing whether a seriously mentally disabled death row defendant is competent to be executed. The Supreme Court's 2007 decision in Panetti $v$. Quarterman significantly expanded its jurisprudence by ruling that such a defendant had a constitutional right to make a showing that his mental illness "obstruct[ed] a rational understanding of the State's reason for his execution." This article considers the impact of neuroimaging testimony on post-Panetti competency determination hearings, and looks at multiple questions of admissibility of evidence, adequacy of counsel, availability of expert assistance, juror attitudes, trial tactics, and application of the Daubert doctrine, and also considers the implications of the lesser-known Panetti holding (that enhances the role of expert witnesses in all competency-to-be-executed inquiries). It warns that the power of the testimony in question has the capacity to inappropriately affect fact-finders in ways that may lead "to outcomes that are both, factually and legally inaccurate and constitutionally flawed." Copyright (C) 2010 John Wiley \& Sons, Ltd.

Scholars have begun to consider the impact of neuroimaging evidence on capital punishment trials, questioning whether reliance on such testimony can actually make "sentencing more rational and humane." They have also considered the impact of this evidence on criminal sentencing, expressing concern that such evidence will be improperly used "as predictive factors to increase sentences," and counseling policymakers to "avoid misuse of new techniques." In earlier articles on neuroimaging and criminal procedure, this author has considered (1) the questions of a criminal defendant's competency to submit to neuroimaging testing, and the impact of antipsychotic medications on the results of such testing, ${ }^{3}$ and (2) the likely impact of

\footnotetext{
${ }^{*}$ Correspondence to: Michael L. Perlin, J.D., Professor and Director, International Mental Disability Law Reform Project; Director, Online Mental Disability Law Program, New York Law School, 185 W. Broadway, New York, NY 10013, U.S.A. E-mail: michael.perlin@nyls.edu

${ }^{\dagger}$ Portions of this article were presented at the annual conference of the American College of Forensic Psychiatry (April 2008), the American Academy of Psychiatry and Law (October 2009), the National Academy of Neuropsychology (November 2009), the Stanford Law School, Center for Law and Biosciences (February 2010), and the University of Pennsylvania Forensic Psychiatry Workshop series (April 2010).

1 See, e.g., O. Carter Snead, Neuroimaging and the "Complexity" of Capital Punishment, 82 N.Y.U. L. REv. 1265,1338 (2007).

${ }^{2}$ See, e.g., Henry Greely, Neuroscience and Criminal Fustice: Not Responsibility but Treatment, 56 U. KAN. L. Rev. 1103, 1104-05 (2008).

${ }^{3}$ Michael L. Perlin, "And I See Through Your Brain": Access To Experts, Competency To Consent, And The Impact Of Antipsychotic Medications In Neuroimaging Cases In The Criminal Trial Process, 2009 STANFORD TECH. L. J. 4 (2009); see also, Michael L. Perlin, \& Valerie McClain, Unasked (and Unanswered) Questions About the Role of Neuroimaging in the Criminal Trial Process, 28 Amer. J. Forens. PsYchology - (2010) (in press).
} 
neuroimaging testimony on juror attitudes in insanity defense cases (where jurors are likely to be highly suspicious of the defendant's "story").

What has not yet been considered is the potential significance of such evidence on an issue that combines aspects of these inquiries from one singular perspective: its potential impact on cases determining whether a seriously mentally disabled death row defendant is competent to be executed.

In Panetti v. Quarterman, ${ }^{5}$ the Supreme Court ruled that such a defendant had a constitutional right to make a showing that his mental illness "obstruct[ed] a rational understanding of the State's reason for his execution," 6 expanding its jurisprudence in this area beyond its earlier decision in Ford $v$. Wainwright that had regularly been interpreted to require that competency to be executed depended only on three findings: that the prisoner is aware that he committed the murders, he is aware that he is going to be: executed, and he is aware of the reasons the State has given for his execution. ${ }^{8}$

Although it is too early to come to any definitive conclusions as to the "real life" implementation of Panetti, we know that prior to Panetti, in many jurisdictions, implementation of Ford was simply nonexistent, ${ }^{9}$ suggesting that fact-finders were utterly disinterested in the testimony presented at hearings designed to thwart execution in cases where it was alleged that the defendant did not meet the Ford standard. Few of these cases considered neuroimaging testimony at all. ${ }^{10}$

Contrarily, Panetti suggests that competency-to-be-executed hearings may necessarily have to become more sophisticated and complex, especially in light of the other Panetti holding that the trial court's failure to provide the defendant an adequate opportunity to submit expert evidence in response to the report filed by the court-appointed experts ${ }^{11}$ deprived him of his "constitutionally adequate opportunity to be heard."12 This also

\footnotetext{
4 Michael L. Perlin, "His Brain Has Been Mismanaged with Great Skill': How Will furors Respond to Neuroimaging Testimony in Insanity Defense Cases?, 42 Akron L. REv. 885 (2009).

5127 S. Ct. 2842 (2007).

6 Id. at 2860. See infra Part II.

7477 U.S. 399 (1986).

8 Panetti, 127 S. Ct. at 2860 , quoting Panetti v. Dretke, 448 F. 3d 815, 819 (5 $5^{\text {th }}$ Cir. 2006), reversed, Panetti v. Quarterman, 127 S. Ct. 2842 (2007).

9 Panetti's lawyers told the Supreme Court in their petition for certiorari that two decades had passed since Ford was decided, and the Fifth Circuit had yet to find a single death row inmate incompetent to be executed. During this same period, the State of Texas executed 360 people. Panetti v. Quarterman, 2006 WL 3880284, *26 (2006) (appellant's petition for certiorari).

${ }^{10}$ Only in Coe v. Bell, 89 F.Supp.2d 922 (M.D.Tenn. 2000) did a court consider MRI and PET scans in the specific context of a Ford hearing (defendant found competent to be executed). In a series of other cases, courts found that neuroimaging evidence was not sufficient to support a finding of mental retardation. See e.g., Kimbrough v. Crosby, 2008 WL 544867 (M.D.Fla. 2008) (PET scan showed no evidence of "brain abnormality"); Simpson v. Quarterman, 2007 WL 1008193 (E.D.Tex. 2007) (MRI revealed no evidence of "brain damage"); State v. Grell, 135 P.3d 696 (Ariz. 2006) (PET scans revealed no "brain damage") And, in rejecting an application for a stay of execution, a court ruled that "denial of the MRI and SPECT procedures requested by Plaintiff does not violate due process.' Allen v. Hickman 407 F.Supp.2d 1098, 1104 (N.D.Cal. 2005).

11 Panetti, 127 S. Ct. at 2857.

12 Id. at 2858 . The fact-finding procedures on which the trial court relied, it concluded, were "not adequate for reaching reasonably correct results' or, at a minimum, resulted in a process that appeared to be "seriously inadequate for the ascertainment of the truth."' Id. at 2859, quoting, in part, Ford, 477 U.S., at 423-24 (Powell, J., concurring in part and concurring in judgment) (internal quotation marks omitted).
} 
leads to the question explored in this article: what impact will neuroimaging testimony have on future Panetti hearings?

This question subsumes multiple sub-questions.

- Will defense counsel seek to introduce such testimony, and what, exactly, can we expect such testimony will say?

- In cases involving indigent defendants, will Ake v. Oklahoma ${ }^{13}$ be interpreted expansively or restrictively? ${ }^{14}$

- Will prosecutors seek to introduce such testimony to rebut defendants' Panetti applications?

- To what extent are judges more or less impervious to the "dazzle" or "Christmas tree effect" of such testimony than are jurors? ${ }^{15}$

- How will such testimony be dealt with if there is a Daubert challenge? ${ }^{16}$

- How will fact-finders deal with such testimony in cases where the evidence revealed by neuroimaging testimony does not comport with their (false) "ordinary common sense" view of "crazy" criminal defendants?"

- How will the less well known aspect of Panetti (that which deals with the need for additional expert testimony) be treated in such cases?

- What, actually, will neuroimagers do in such cases?

This article seeks to offer some preliminary answers to these questions. The first section briefly reviews attitudes that scholars have expressed about the use of neuroimaging in the courts in criminal cases. The second section briefly discusses the Panetti case. The third section seeks to answer the questions raised above. The fourth section offers some tentative conclusions.

In the final verse of Bob Dylan's masterpiece, My Back Pages, Dylan captures the ambivalence of absolute terms:

Yes, my guard stood hard when abstract threats

Too noble to neglect

Deceived me into thinking

I had something to protect

Good and bad, I define these terms

Quite clear, no doubt, somehow

Ah, but I was so much older then

I'm younger than that now. ${ }^{18}$

\footnotetext{
${ }^{13} 470$ U.S. 68,74 (1985) (indigent defendant's right to insanity defense expert).

${ }^{14}$ On $A k e$ generally in a neuroimaging context, see Perlin, supra note 3.

15 On juror response to such testimony in insanity defense cases, see Perlin, supra note 4.

16 See Daubert v. Merrill Dow Pharmaceuticals Inc, 509 U.S. 579 (1993) (in determining whether to admit scientific evidence, must consider three factors: (1) the reliability, (2) the relevancy, and (3) the possible prejudicial nature of the evidence). See text infra notes 122-35.

17 Compare Michael L. Perlin, "She Breaks fust Like a Little Girl: Neonaticide, The Insanity Defense, and the Irrelevance of Ordinary Common Sense," 10 WM. \& MARY J. WOMEN \& L. 1 (2003) (discussing "ordinary common sense" (OCS)).

${ }^{18} \mathrm{http}: /$ www.bobdylan.com/\#/songs/my-back-pages (accessed May 18, 2010). This author has drawn on this song as inspiration for articles twice previously. See Michael L. Perlin, "Half-Wracked Prejudice Leaped Forth"; Sanism, Pretextuality, and Why and How Mental Disability Law Developed As It Did, 10 J. CoNTEMP. LEG. Iss. 3 (1999) (Perlin, Half-Wracked Prejudice); Michael L. Perlin \& John Douard, "Equality, I Spoke That Word/As If a Wedding Vow"; Mental Disability Law and How We Treat Marginalized Persons, 53 N.Y.I. ScH. L. REv. 9 (2008-09). The author wishes to thank Dr. Ken Weiss for the specific lyric suggestion.
} 
The literature (and judicial opinions) about neuroimaging reflect precisely this ambivalence (that it is "quite clear"... "somehow"). One aim of this article is to consider the implications of this ambivalence for the topic addressed here. ${ }^{19}$

\section{NEUROIMAGING AND THE COURTS: AN OVERVIEW}

A review of the literature on neuroimaging, predictably, reveals a broad array of positions, promises and prophecies. Carter Snead argues that the ambition of cognitive neuroscientists is "to use the claims of their discipline and the new powers conferred by neuroimaging to overthrow retributive justice as a legitimate justification for criminal sanctions." 20 Jonathan Marks quotes William Uttal's warning that neuroimaging may be simply a "neo-phrenological fad." ${ }^{\text {"21 }}$ David Eagleman claims that "There is a new potential to use detailed combinations of behavioral tests and neuroimaging to better predict recidivism."22 Steven Erickson argues that "it is inescapable that the novel and powerful technology of brain imaging drives [neuroscientists'] conception of the mind." 23 Perhaps most emphatically, Bruce Arrigo charges that "the mass marketing and wholesale circulation of fMRI technology sustains the very structural inequalities (both social and psychological) that result in destructiveness, violence and crime."24

This article consciously sidesteps this philosophical debate ${ }^{25}$ and focuses instead on a related, but distinctly separate issue: what impact, in terms of case outcomes, will this evidence have on a small, but powerfully important and vivid, subset of cases-whether defendants sentenced to death are competent to be executed? ${ }^{26}$

When jurors construe neuroimaging evidence in insanity defense $\operatorname{cases}^{27}$ their response is likely highly ambivalent: balancing a positive response to the perceived characteristics of this evidence-vivid, objective, quantifiable, advanced ${ }^{28}$ - with a negative response to the use of this evidence in such cases (reflecting their prejudice,

\footnotetext{
19 The questions I raise in this article clearly have implications far beyond the more narrow issue of neuroimaging testimony. I believe, however, that this specific focus is valuable in itself as it is a subtopic that will inevitably grow in significance in the coming years.

${ }^{20}$ Snead, supra note 1 , at 1316 .

21 Jonathan H Marks, Interrogational Neuroimaging in Counterterrorism: A "No-Brainer" or Human Rights Hazard, 33 Am. J.L. \& Med. 483, 492 (2007), quoting William UtTal, The New Phrenology: The Limits of Localizing Cognitive Processes in the Brain (2003).

22 David Eagleman, Neuroscience and the Law, 45 HOUS. LAWYER 36, 38 (April 2008). For an extensive list of what such evidence might be used for both in criminal trials and in the context of criminal policy decisionmaking, see Jeff Victoroff, Aggression, Science and the Law, 32 Int'l J. L. \& Psychiatry189, 194 (2009).

${ }_{23}$ Steven Erickson, Blaming the Brain, 11 MINN. J.L. ScI. \& TECH. 27, 32 (2010).

24 Bruce Arrigo, Punishment, Freedom, and the Culture of Control: The Case of Brain Imaging and the Law, 33 Ам. J.L. \& MED. 457, 480 (2007). On the impact of the "prestige of science" in criminal procedure jurisprudence," see Simon Cole \& Rachel Dioso-Villa, Investigating the "CSI Effect" Effect: Media and Litigation Crisis in Criminal Law, 61 STAN. L. REv. 1335, 1373 (2009) (focusing on the impact of the so-called "CSI effect).

${ }^{25}$ I do this not because the debate is trivial, but because my focus here is on the one specific question of the use of this evidence in the criminal trial process. At this point in time, the philosophical positions discussed above have not surfaced in any meaningful way in the handful of court decisions that have considered this question. When that happens, I will certainly return to this question.

${ }^{26}$ For a survey of the different diagnostic techniques that might be used in this context, see Bethany Bryant, Expanding Atkins and Roper: a Diagnostic Approach to Excluding the Death Penalty as Punishment for Schizophrenic Offenders, 78 Miss. L.J. 905, 924-25 (2009).

27 See generally, Perlin, supra note 4 . This is another subset of criminal cases highly susceptible to the use and misuse of the vividness heuristic. See Perlin, supra note 17, at 4 . The vividness heuristic is a cognitive-simplifying device through which a "single vivid, memorable case overwhelms mountains of abstract, colorless data upon which rational choices should be made," and further accentuates a misperception of reality. See Perlin, supra note 3, at *24.

${ }^{28}$ Perlin, supra note 4, at 890 ("this language jumps off the page").
} 
hostility, and hatred toward insanity pleaders). ${ }^{29}$ It is not certain that "the pizzazz of neuroimaging testimony-not withstanding its colorfulness and its propensity to reductionism - will trump these deep-seated attitudes." 30 The science of neuroscience, in short, has to be assessed in the sociopolitical context of the specific question of law that is central to the specific case before the court.

Neuroimaging is "fraught with uncertainties." 31 The steps used in the production and presentation of neuroimaging evidence are "not only not standardized, they are easily manipulated by a person with the knowledge of the technology." 32 Some researchers characterize it as "indistinct." 33 Amanda Pustilnik, by way of example, concludes, "neuroscience cannot provide complete, or even sufficient, explanations of criminal violence by reference primarily to purported neurobiological dysfunctions within isolated parts of offenders' brains."34 Other scholars charge that "researchers, clinicians, and lawyers are seduced into becoming true believers in the merits of [brain imaging] for understanding the relationship between brain and behavior." 35 Stacey Tovino argues that the fMRI offers only "an illusory accuracy and objectivity." 36 But what is clear is that the existence of neuroimaging techniques has changed the contours of the playing field. ${ }^{37}$ This is a reality that must be acknowledged.

\section{PANETTI}

In 1986 , in the case of Ford $v$. Wainwright, ${ }^{38}$ a sharply fractured Supreme Court held that the Eighth Amendment prohibited the imposition of the death penalty on an insane prisoner. ${ }^{39}$ On the question of what procedures were appropriate in such a case, the court was sufficiently fragmented that no opinion commanded a majority of justices. In a four-Justice opinion, Justice Marshall concluded that the ascertainment of a prisoner's

\footnotetext{
29 See generally, Michael L. Perlin, The Jurisprudence of the Insanitry Defense (1994). See also, e.g., Perlin, supra note 17, at 10 n.54, discussing Judith S. Neaman, Suggestion of the Devil: The Origins of MadNEss 31, 144 (1975) (addressing the stereotype of persons with mental illness as evil); Michael L. Perlin, 'There Was an Evil Messenger": Blame, Mental Illness, Wickedness, the Insanity Defense and the Pretexts of the Fustice System (paper presented at $30^{\text {th }}$ Annual Congress, International Academy of Law and Mental Health, Padua, Italy, June 2007) (same); Michael L. Perlin, Unpacking the Myths: The Symbolism Mythology of Insanity Defense furisprudence, 40 CASE W. RES. L. REv. 599, 626 (1989-90) (" [historically], mental illness was tied to notions of religion and traditionally seen as God's punishment for $\sin ^{\text {') }}$.

30 See Perlin, supra note 4, at 911.

31 Alexandra Roberts, Everything New is Old Again: Brain Fingerprinting and Evidentiary Analogy, 9 Y ALE J.L. \& TECH. 234, 266 n.155 (2006-07).

32 Donald R. Reeves et al, Limitations of Brain Imaging in Forensic Psychiatry, 31 J. AM. ACAD. PsYchIATRY \& L. 89,90 (2003).

${ }^{33}$ Timo Vloet et al, Structural and Functional MRI Findings in Children and Adolescents with Antisocial Behavior, 26 Behav. ScI. \& L. 99, 99 (2008).

34 Amanda Pustilnik, Violence on the Brain: A Critique of Neuroscience in Criminal Law, available at http:// ssrn.com/abstract $=111250$, manuscript at 5 .

${ }^{35}$ Laurence Tancredi \& Jonathan Brodie, The Brain and Behavior: Limitations in the Legal Use of Functional Magnetic Resonance Imaging, 33 AM. J. L. \& MED. 271, 289 (2007).

36 Stacey A. Tovino, Functional Neuroimaging Information: A Case for Neuro Exceptionalism?, 34 FLA. ST. U. L. Rev. 415, 479 (2006), quoting Martha J. Farah, Emerging Ethical Issues in Neuroscience, 5 NatuRE REv. NEURoscience 1123, 1127 (2002).

37 See, e.g., Erickson, supra note 23, at 29 ("The impact of neuroscience on the law in the coming years will be inevitable, dramatic, and will fundamentally alter the way the law does business') (emphasis added).

${ }^{38} 477$ U.S. 399 (1986). See generally, 4 Michael. L. Perdin, Mental Disability Law: Civil and Criminal $\S \S$ $12-4$ to $12-4.13$, at $519-44$ ( $2 \mathrm{~d}$ ed. 2002 ).

39 Id. at $405-10$.
} 
sanity "as a lawful predicate to execution calls for no less stringent standards than those demanded in any other aspect of a capital proceeding," 40 a standard particularly demanding in light of the reality that "the present state of the mental sciences is at best a hazardous guess however conscientious."41

Ford has been interpreted narrowly, the lower courts regularly finding that competency was to be determined solely by an inquiry into whether a prisoner is aware "“that he [is] going to be executed and why he [is] going to be executed." ${ }^{42}$ Certiorari was granted in the Panetti case-at least in part - to clarify the Ford ruling.

Panetti, who had been convicted of capital murder in the slayings of his estranged wife's parents, had been hospitalized numerous times for serious psychiatric disorders. ${ }^{43}$ Notwithstanding his "bizarre," scary", and "trance-like" behavior, he was found competent to stand trial and competent to waive counsel. ${ }^{44} \mathrm{He}$ was convicted (the jury rejecting his insanity defense), and was sentenced to death. ${ }^{45}$ After his direct appeals and initial petition of habeas corpus were rejected, ${ }^{46}$ Panetti filed a subsequent habeas writ petition, alleging that he did not understand the reasons for his pending execution. ${ }^{47}$ This petition was rejected, the court concluding that the test for competency to be executed "requires the petitioner know no more than the fact of his impending execution and the factual predicate for the execution." 48 The Fifth Circuit affirmed, ${ }^{49}$ and the Supreme Court granted certiorari. ${ }^{50}$

The court reversed in a 5-4 decision, and in the course of its opinion ${ }^{51}$ significantly elaborated on its Ford opinion in two dimensions: as to the procedures that are to be afforded to a defendant seeking to assert a Ford claim, and as to the substance of the Ford standard.

\footnotetext{
40 Id. at $411-12$.

41 Solesbee, 339 U.S. 339 U.S. 9, 23 (1950) (Frankfurter, J., dissenting). See also O'Connor v. Donaldson, 422 U.S. 563, 584 (1975) (Burger, C.J., concurring) ("there are many forms of mental illness that are not understood"); Addington v. Texas, 441 U.S. 418, 429 (1979) ("Given the lack of certainty and the fallibility of psychiatric diagnosis, there is a serious question as to whether a state could ever prove beyond a reasonable doubt that an individual is both mentally ill and likely to be dangerous").

42 Panetti, 448 F.3d, at 819; see also id. at 818 (discussing Ford, 477 U.S., at 421-422 (Powell, J., concurring in part and concurring in judgment)).

43 Panetti, 127 S.Ct. at 2848.

44 Id.; see Michael L. Perlin, "Dignity Was the First to Leave": Godinez v. Moran, Colin Ferguson, and the Trial of Mentally Disabled Criminal Defendants, 14 BeHAv. SCI. \& L. 61 (1996).

45 Panetti, 127 S. Ct. at 2849.

46 Id.

47 Id.

48 Panetti v. Dretke, 401 F. Supp. 705, 711 (W.D. Tex. 2004).

49 Panetti v. Dretke, 448 F. 3d 815 ( $5^{\text {th }}$ Cir. 2006)

50 Panetti v. Quarterman, 127 S. Ct. 852 (2007).

51 In a jurisdictional ruling of great importance to death penalty litigation, the court also found that the defendant's claim was not barred by federal legislation that generally prohibited "successive" habeas corpus applications. See Panetti v. Quarterman, 127 S. Ct. 2842, 2852-55 (2007). The significance of this portion of the opinion is beyond the scope of this paper.

It was expected that the Supreme Court would also rule on another issue in Panetti: the right of an incompetent death row inmate to refuse medication designed to make him competent to be executed. Compare e.g., State v. Perry, 610 So. 2d 746 (La. 1992) (right to refuse), and Singleton v. State, 437 S.E.2d 53, 60-62 (S.C. 1993) (same), to Singleton v. Norris, 992 S.W.2d 768 (Ark. 1999) (no such right). The court did not address that question. See Michael L. Perlin, Insanity Is Smashing up Against My Soul: Panetti v. Quarterman and Questions That Won't Go Away, available at http://papers.ssrn.com/sol3/ papers.cfm?abstract_id=1130890.
} 
On the first matter, it found error below in the trial court's failure to provide the defendant an adequate opportunity to submit expert evidence in response to the report filed by the court-appointed experts, ${ }^{52}$ thus depriving him of his "constitutionally adequate opportunity to be heard." 53 The fact-finding procedures on which the trial court relied, it concluded, were "'not adequate for reaching reasonably correct results' or, at a minimum, resulted in a process that appeared to be 'seriously inadequate for the ascertainment of the truth." 54

On the second, it carefully elaborated on-and clarified-Ford. It reviewed the testimony that demonstrated the defendant's "fixed delusion" system, ${ }^{55}$ and quoted with approval expert testimony that had pointed out that "an unmedicated individual suffering from schizophrenia can 'at times' hold an ordinary conversation and that 'it depends [whether the discussion concerns the individual's] fixed delusional system." "56 Here, it rejected the Court of Appeals' interpretation of the Ford standard-that competency to be executed depends only on three findings: that the prisoner is aware he committed the murders, that he is aware that he is going to be executed, and that he is aware of the reasons the State has given for his execution. ${ }^{57}$

This narrow test, the Supreme Court concluded, unconstitutionally foreclosed the defendant from establishing incompetency by the means that Panetti sought to employ in the case at bar: by making a showing that his mental illness "obstruct[ed] a rational understanding of the State's reason for his execution." 58 The Fifth Circuit had squarely confronted this issue, and had found that "awareness" was "not necessarily synonymous with "rational understanding"; ; 59 the Supreme Court rejected this position, finding that it was "too restrictive to afford a prisoner the protections granted by the Eighth Amendment.",60

In this case, the court found, the Fifth Circuit improperly treated a prisoner's delusional belief system "as irrelevant if the prisoner knows that the State has identified his crimes as the reason for his execution."61 Nowhere, the court continued, did Ford indicate that 'delusions are irrelevant to 'comprehen[sion]' or 'aware [ness]' if they so impair the prisoner's concept of reality that he cannot reach a rational understanding of the reason for the execution." 62 If anything, the court continued, "the Ford majority suggests the opposite." 63

\footnotetext{
52 Panetti, 127 S. Ct. at 2857.

53 Id. at 2858 .

54 Id. at 2859, quoting, in part, Ford, 477 U.S., at 423-24 (Powell, J., concurring in part and concurring in judgment) (internal quotation marks omitted).

55 Panetti, 127 S. Cr. at 2859. See id:

Four expert witnesses testified on petitioner's behalf in the District Court proceedings. One explained that petitioner's mental problems are indicative of "schizo-affective disorder," resulting in a "genuine delusion" involving his understanding of the reason for his execution. According to the expert, this delusion has recast petitioner's execution as "part of spiritual warfare ... between the demons and the forces of the darkness and God and the angels and the forces of light." As a result, the expert explained, although petitioner claims to understand "that the state is saying that [it wishes] to execute him for [his] murder[s]," he believes in earnest that the stated reason is a "sham" and the State in truth wants to execute him "to stop him from preaching." Petitioner's other expert witnesses reached similar conclusions concerning the strength and sincerity of this "fixed delusion." (citations to record omitted).

56 Id. at 2860

57 Id. at 2860.

58 Id., quoting Panetti, 448 F. 3d at 819.

59 Panetti, 448 F. 3d at 817-18.

60 Panetti, 127 S. Ct. at 2860.

61 Panetti, 448 F. 3d at 817-18.

${ }^{62}$ Id.

63 Id.
} 
After quoting the "simply offends humanity" language from Ford, ${ }^{64}$ the court focused on the reasons why executing an insane person "serves no retributive purpose": 65

[I] t might be said that capital punishment is imposed because it has the potential to make the offender recognize at last the gravity of his crime and to allow the community as a whole, including the surviving family and friends of the victim, to affirm its own judgment that the culpability of the prisoner is so serious that the ultimate penalty must be sought and imposed. The potential for a prisoner's recognition of the severity of the offense and the objective of community vindication are called in question, however, if the prisoner's mental state is so distorted by a mental illness that his awareness of the crime and punishment has little or no relation to the understanding of those concepts shared by the community as a whole. This problem is not necessarily overcome once the test set forth by the Court of Appeals is met. And under a similar logic the other rationales set forth by Ford fail to align with the distinctions drawn by the Court of Appeals. ${ }^{66}$

There was no support in Ford ("or anywhere else"), the court added, for the proposition that "a prisoner is automatically foreclosed from demonstrating incompetency once a court has found he can identify the stated reason for his execution." 67 Although it conceded that concepts such as "rational understanding" could be difficult to define, and that some might fail to be punished on account of "reasons other those stemming from a severe mental illness," it concluded, on this point, "The beginning of doubt about competence in a case like petitioner's is not a misanthropic personality or an amoral character. It is a psychotic disorder." ${ }^{\prime \prime 8}$ In this case, it again underlined, it was the prisoner's "severe, documented mental illness that is the source of gross delusions preventing him from comprehending the meaning and purpose of the punishment to which he has been sentenced." 69

After coming to this conclusion, the court added that it was not attempting to set out a rule to govern all competency determinations, and then remanded so that the "underpinnings of petitioner's claims [could] be explained and evaluated in further detail on remand. ${ }^{.70}$ Among the questions it sought to be explored in greater depth was "the extent to which severe delusions may render a subject's perception of reality so distorted that he should be deemed incompetent," citing here an aspect of the amicus brief by the American Psychological Association that had discussed ways in which mental health experts can inform competency determinations. ${ }^{71}$

Panetti will be an enormously significant opinion with regard to the underlying issues for at least two reasons: it fleshes out the constitutionally adequate procedural standards for making a determination on execution competency (by demanding that defendants have the opportunity to submit adequate expert evidence to respond to evidence on competency "solicited by the state court" as part of the defendant's "constitutionally adequate opportunity to be heard"), ${ }^{72}$ and it clarifies the Ford substantive test to demand

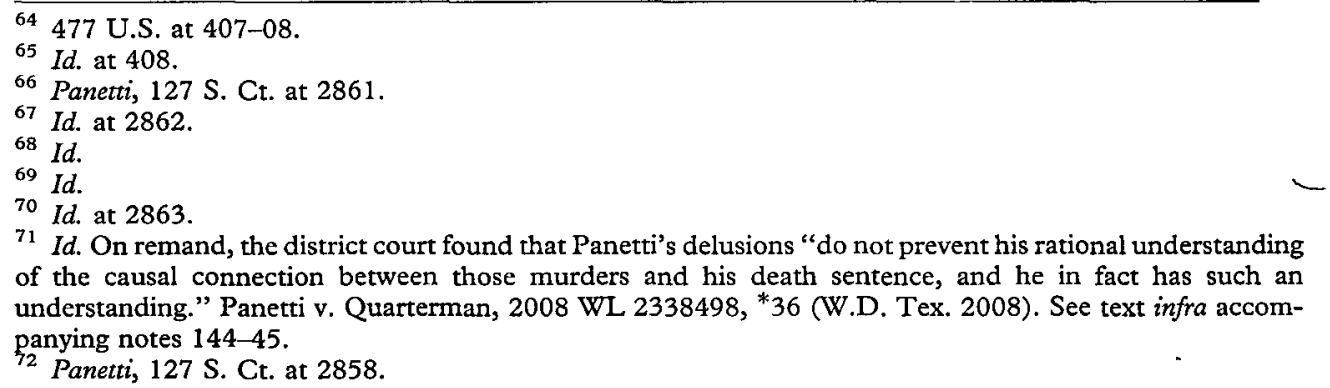


that the prisoner possess a "rational understanding"73 of the reasons he is to be executed. ${ }^{74}$

The court's opinion also expands the role of the expert witness in competency determinations. First, its procedural prong tells us that the trial court's failure to allow the defendant to introduce evidence on this question was a failure of constitutional dimensions. Second, its conclusion's citation to the American Psychological Association's amicus brief (that had discussed the ways that experts can inform competency determinations) tells us that a majority of this court (albeit a bare majority) is comfortable with (and responsive to) a greater role for mental health experts in judicial proceedings. We cannot underestimate the significance of this attitude.

Post-Panetti cases have not been particularly helpful. Few have discussed neuropsychological testing at all, and none have examined the questions raised here in the context of the Panetti holding. ${ }^{75}$ On the other hand, several cases have underscored the fundamental difference between the Panetti holding and the Ford holding, ${ }^{76}$ have considered the application of Panetti to claims brought under Atkins $v$. Virginia, ${ }^{77}$ and the application of the Panetti reasoning in non-death penalty cases to determinations of competency to be sentenced. ${ }^{78}$

73 Id. at 2860 .

74 See Pamela A. Wilkins, Competency for Execution: the Implications of a Communicative Model of Retribution,76 TENN. L. Rev. 713, 742 (2009): "The good news from Panetti is that the Court finally articulated a specific justification for the Eighth Amendment ban: the execution of an incompetent inmate lacks retributive value." See generally, Bruce Winick, The Supreme Court's Evolving Death Penalty Furisprudence: Severe Mental Ilness As The Next Frontier, 50 B.C. L. REv. 785 (2009); Jeffrey Kirchmeier, The Undiscovered Country: Execution Competency \& Comprehending Death, 98 KY. L. REv. 263 (2009-10).

${ }^{75}$ A simple WESTLAW ALLCASES search ("panetti v. quarterman" \& neuroimaging neuroscience "pet scan" "spect scan" mri fmri) reveals a universe of only six cases, none of which raise this specific issue in this context. See Dillbeck v. McNeil, 2010 WL 419401 (N.D. Fla. 2010); Jones v. Ryan, 583 F. 3 d $626\left(9^{\text {th }}\right.$ Cir. 2009); Walls v. McNeil, 2009 WL 3187066 (N.D. Fla. 2009); Sireci v. Secretary, Fla. Dep't of Corrections, 2009 WL 651140 (M.D. Fla. 2009); Kimbrough v. Crosby, 2008 WL 544867 (M.D. Fla, 2008); Woodall v. Simpson, 2008 WL 5666261 (W.D. Ky. 2008). Compare Chris Koepke, Panetti v. Quarterman: Exploring the Unsettled and Unsettling, 45 Hous. L. REv. 1383, 1404 (2008) (Panetti leaves "a tremendous number of issues for lower courts to resolve").

Panetti has not been cited on the competency issue by the US Supreme Court in the three years since the case was decided (see SCT database on WESTLAW, last accessed September 15, 2010).

${ }_{76}$ See, e.g., Thompson v. Bell, 580 F. $3 \mathrm{~d} 423,434\left(6^{\text {th }}\right.$ Cir. 2009) (noting that Panetti "clarifie[d]" Ford, and that the state court's decision rejecting the defendant's claim was "unreasonable" under Panetti).

77536 U.S. 304 (2002) (defendant's mental retardation barred the imposition of the death penalty); see Rivera v. Quarterman, 505 F. 3d 349, 358 (5th Cir. 2007) ("The lesson we draw from Panetti is that, where a petitioner has made a prima facie showing of retardation as Rivera did, the state court's failure to provide him with the opportunity to develop his claim deprives the state court's decision of the deference normally due"); see also, e.g., Hearn v. Quarterman, 2008 WL 679030, *3 (N.D. Tex. 2008):

Although the court finds that Hearn's counsel, through the exercise of due diligence and reasonable competence, could have concluded earlier than he did that evidence of Hearn's neuropsychological deficits and fetal alcohol syndrome might satisfy the "significant limitations in intellectual functioning" element of the mental retardation definition, and that his counsel could have secured supporting expert testimony before responding to the state's summary judgment motion, this factor is outweighed by the importance of the new evidence and the fact that the state is unlikely to suffer unfair prejudice as a result of granting the requested relief.

Hearn was subsequently supplemented in Hearn v. Quarterman, 2008 WL3362041, *7 (N.D. Tex. 2008),

finding that Hearn's prima facie showing of mental retardation supported his conclusion that an Atkins claim was "potentially meritorious."

${ }^{78}$ See, e.g., United States v. Wolfson, 616 F. Supp. 2d 398, 420 (S.D.N.Y. 2008): The principles that the Court explained in Panetti spring from the Court's interpretation of "rational understanding" as applied to an execution for purposes of the Eighth Amendment. The same requirement of "rational understanding" applies to the determination of competence under the due process clause. 


\section{QUESTIONS TO CONSIDER}

This all leads to an examination of the questions listed above: How will neuroimaging testimony be dealt with in post-Panetti death penalty cases? This issue has not yet been resolved in any reported case, but it is inevitable that the issue will be confronted by the courts in the near future. Consider the following issues.

1. Will defense counsel seek to introduce such testimony, and what, exactly, can we expect such testimony will say?

My answer here is a qualified "maybe," dependent on multiple interlocked variables:

- Will courts be receptive to neuroimaging testimony that seeks to answer the specific substantive question posed by Panetti: did the defendant possess "a rational understanding of the State's reason for his execution"? ${ }^{79}$ Such testimony has been introduced-with mixed results - in cases where defendants have sought to assert their incompetency to stand trial or their lack of responsibility for the underlying criminal offense. ${ }^{80}$ The two most notorious cases in this cohort are the cases of Vincent "The Chin" Gigante and John Hinckley, ${ }^{81}$ but such evidence has also been introduced in a range of less familiar cases dealing with such questions as potential reduction in degrees of homicide, ${ }^{82}$ the capacity of a defendant to plead guilty, ${ }^{83}$ and the penalty phase of a death penalty trial. ${ }^{84}$ How will courts react when the question is whether the defendant is even eligible for the death penalty?

- Will defense counsel even think about this question? This returns us to the question of the inevitability of substandard quality of counsel often made available to defendants in death penalty cases. ${ }^{85}$ All too often, such lawyers are, in Judge Bazelon's

79 Panetti, 128 S. Ct. at 2860.

80 On the specific question of the value of neuroimaging evidence in discovering brain lesions that might affect criminal responsibility, see Shelley Batts, Brain Lesions and Their Implications in Criminal Responsibility, 27 BeHAv. SCI. \& L. 261 (2009). On the potential impact of neuroimaging on insanity defense perspectives from a forensic psychiatry perspective, see J. Arturo Silva, Forensic Psychiatry, Neuroscience, and the Lazw, 37 J. AM. ACAD. Psychiatry \& L. 489 (2009).

${ }_{81}$ See Perlin, supra note 4 , at $895-98$. There have been other locally- and regionally-high profile cases involving neuroimaging testimony. See, e.g., United States v. Mezvinsky, 206 F. Supp. 2d 661 (E.D. Pa. 2002) (multi-million dollar fraud case; defendant was former Congressman); People v. Goldstein, 786 N.Y.S. $2 \mathrm{~d}$ 428 (A.D. 2004), rev'd on other gds., 843 N.E. $2 d 727$ (N.Y. 2005) (murder case in which victim was Kendra Webdale, after whom NY's assisted outpatient treatment law was named).

82 Jane Moriarty, Flickering Admissibility: Neuroimaging in the U.S. Courts, 26 BeHAv. ScI. \& L. 29, 39 (2008); see also, Snead, supra note 1, at 1298; Amanda Pustilnik, Violence on the Brain: A Critique of Neuroscience in Criminal Law, 44 WaKe Forest L. Rev. 183, 185 n. 9 (2009)(listing cases where such testimony has been offered by defendants at the mitigation stage of a death penalty case). See, e.g., United States v. Williams, 2009 WL 424583,**5-6 (D. Hawai'i 2009) (discussing the debate as to the reliability of fMRI scans, and citing, inter alia, to Laura Khoshbin \& Shahram Khoshbin, Imaging the Mind, Minding the Image: An Historical Introduction to Brain Imaging and the Law, 33 AM. J. L. \& MED. 171 (2007) (discussed infra text accompanying notes 113-14).

${ }_{83}$ Moriarty, supra note 82 , at 44 .

84 Id. at 45; Snead, supra note 1, at 1308 n. 215. See, e.g., State v. Holmes, 5 So. 3d 42 (La. 2008 ).

85 See Michael L. Perlin, "Life Is in Mirrors, Death Disappears"': Giving Life to Atkins, 33 N. MEX. L. REv. 315 , 335 (2003) (Perlin, Death Disappears) ("The quality of counsel in providing legal representation to mentally disabled criminal defendants is a disgrace'); see also generally, Michael L. Perlin, "The Executioner's Face Is Always Well-Hidden": The Role of Counsel and the Courts in Determining Who Dies, 41 N.Y.L. SCH. L. REv. 201 (1996) (Perlin, Executioner's). 
unforgettable phrase, "walking violations of the Sixth Amendment."86 Is it too much to hope for to expect counsel to "get" the potential value of such testimony in Panettitype cases?

- Assuming counsel doesn't "get it," how will the courts construe the "pallid"87 standard of Strickland $v$. Washington in this context? Is it likely that counsel will be held ineffective ${ }^{88}$ for not seeking this sort of testing? ${ }^{89}$ Or, if it is used, for not understanding its limitations? ${ }^{90}$ An interesting parallel can be found in an investigation by Professor Deborah Denno of the use of behavioral genetics evidence in criminal cases. ${ }^{91}$ Although Professor Denno discusses a handful of cases in which failure to consider such evidence resulted in Strickland-based remands, these cases, she concludes, are a "minority, and courts generally "place... less importance on [this] evidence." 92 Will courts assessing this issue respond in the same way that the courts studied by Professor Denno responded?

- Assuming that counsel does get it, who pays? Neuroimaging testing is expensive, and is more expensive in cases in which the examined defendant is incarcerated when the test is performed. ${ }^{93}$ Services of experts skilled to testify about this testing are also expensive. At a time at which the problem of funding indigent criminal defense has reached crisis proportions, ${ }^{94}$ it is not hard to speculate as to likely trial responses to applications for independent neuroimaging tests.

2. In cases involving indigent defendants, will Ake v. Oklahoma ${ }^{95}$ be interpreted expansively or restrictively? 96

In Ake v.Oklahoma, a death penalty case, the Supreme Court ruled that an indigent criminal defendant who makes a threshold showing that insanity is likely to be a significant factor at trial is constitutionally entitled to a psychiatrist's assistance. ${ }^{97}$

\footnotetext{
86 David L. Bazelon, The Defective Assistance of Counsel, 42 U. Cin. L. Rev. 1, 2 (1973).

87 Perlin, Death Disappears, supra note 85, at 348.

88466 U.S. 668 (1984) (ineffectiveness-of-counsel standard).

89 Compare Jones v. Ryan, 583 F. 3d 626, 636-37 ( $9^{\text {th }}$ Cir. 2009) (defense counsel ineffective at sentencing level for failing to file motion for neuropsychological testing), to Sneed v. Johnson, 2007 WL $709778, * 62$ (N.D. Ohio 2007) (collecting cases where ineffectiveness not found in cases where counsel failed to seek appointment of neuropsychologist); for one example, see Jones v. Schriro, 450 F.Supp.2d 1023, 1044 (D.Ariz. 2006) (defendant presented no evidence that results of CAT scan, MRI or EEG would support a finding of cognitive impairment; no Strickland violation found).

90 See Jane Moriarty, Visions of Deception: Neuroimages and the Search for the Truth, 42 Akron L. REv. 739 (2009); see also, Brian Reese, Using fMRI as a Lie Detector-Are We Lying to Ourselves? 19 ALB. L. J. ScI. \& ТЕсн. 205 (2009).

91 See Deborah Denno, Behavioral Genetics Evidence in Criminal Cases: 1994-2007, in The IMPACT OF Behavioral Sciences on Criminal Law 317 (Nita A. Farahany ed. 2009).

92 Id. at 338.

93 For sample fee scales, see, e.g., http://www.nhhealthcost.org/uninsuredWizardUserInput.aspx?procedure= 16\&procedureName=MRI+-+Brain+(outpatient). See generally, Steve Silberman, Don't Even Think About Lying: How Brain Scans Are Reinventing the Science of Lie Detection, WIRED, Jan. 2006, at 147 (available at http://www.wired.com/wired/archive/14.01/lying.html?pg=4\&topic=lying\&topic_set).

94 See, e.g., Hurrell-Harring v. State, 930 N.E.2d 217 (N.Y. 2010) (criminal defendants stated cognizable claim in ailegations that public defense system was deficient and presented unacceptable risk of denial of constitutional right to counsel); Jennifer Allen, Free For All A Free For All: The Supreme Court's Abdication Of Duty In Failing To Establish Standards For Indigent Defense, 27 LAw \& INEQ. 365, 406 (2009).

95470 U.S. 68,74 (1985) (indigent defendant's right to insanity defense expert).

96 On the relationship between neuroimaging and $A k e$ in general, see Perlin, supra note 3.

$97 \mathrm{Ake}, 470$ U.S. at 74 See generally, 4 PERLIN, supra note $38, \S 9 \mathrm{~A}-5.1$ at $217-27$.
} 
However, the courts have generally read Ake narrowly, and have refused to require appointment of an expert unless it is "absolutely essential to the defense." 98

In his exhaustive survey article about the implementation of $A k e$, Professor Paul Giannelli points out, in a slightly different context, that "in 1985, the $A k e$ Court could not have anticipated how the advent of DNA evidence would revolutionize forensic science." 99 Nor, of course, could it have anticipated the new significance of neuroimaging evidence. To this point in time, however, lower courts have been generally reluctant to extend $A k e$ to requests for funding for neuroimaging tests. ${ }^{100} \mathrm{In}$ Bates v. State, ${ }^{101}$ no $A k e$ violation was found where a defendant sought additional expert assistance in establishing functional organic brain damage, and in Smith v. Kearney ${ }^{102}$ there was no $A k e$ error where defendant sought funds for a PET scan. ${ }^{103}$ Although the court in Walker $v$. Oklahoma ${ }^{104}$ found that it was Ake error to fail to provide funds for additional neurological testing "to flesh out the etiology [of the defendant's] mental illness," 105 it deemed this error harmless. ${ }^{106}$ On the other hand, People v. Fones did reverse a conviction because of the lower court's refusal to fund brain scans. ${ }^{107}$

Confounding this issue is the language in Panetti that appears to envision an expanded role for expert witnesses in this sort of inquiry, finding that trial court's failure to allow the defendant to introduce evidence on this question was a failure of "constitutional dimensions." 108 Will this aspect of Pantti be given life in subsequent decisions? In the non-death-penalty case of Lewis v. Zon, ${ }^{109}$ Panetti was relied on to grant a writ of habeas corpus, the court noting that "not allowing a defendant the opportunity to respond to evidence solicited by the state court to determine trial competency is inconsistent with a defendant's procedural due process right." 110 To

98 Stephen A. Saltzburg \& Daniel J. Capra, American Criminal Procedure 802 (6th ed. 2000). See also David A. Harris, Ake Revisited: Expert Psychiatric Witnesses Remain Beyond Reach for the Indigent, 68 N.C. L. REv. 763, 783 (1990) ("Lower courts often have interpreted $A k e$ less than generously, unduly constricting the availability of the right.'); see also, Comment, Nonpsychiatric Expert Assistance and the Requisite Showing of Need: $A$ Catch-22 in the Post-Ake Criminal fustice System, 37 EMORY L.J. 995 (1988) (arguing Ake should be read to encompass nonpsychiatric expert assistance); Carla Drinan, The Revitalization of Ake: $A$ Capital Defendant's Right to Expert Assistance, 60 OKLA L. REv. 283 (2007).

99 Paul Giannelli, Ake v. Oklahoma: The Right to Expert Assistance in a Post-Daubert, Post-DNA World, 89 CORNELI L. REv. 1305, 1418 (2004).

100 fones is discussed in this context in Jennifer Kulynych, Psychiatric Neuroimaging Evidence: $A$ High-Tech Crystal Ball, 49 STAN. L. Rev. 1249,1254 (1997), and Mark Pettit, FMRI and BF Meet FRE: Brain Imaging and the Federal Rules of Evidence, 33 AM. J. L. \& MED. 319, 335 (2007). For an array of recent post-Ake decisions, see MrchaEL L. PerLIN \& Heather Eu is Cucolo, Mental Disabi ity Law: Civil and Criminal, $\S 9 A-5.1$, at 80 (2009 Cum. Supp.).

101750 So. 2d 6, 16-17 (Fla. 1999).

1022008 WL 2721155 (Ariz. App. 2008).

103 Smith was a challenge based on Atkins v. Virginia, 536 U.S. 304 (2002), arguing that the defendant's mental retardation barred the imposition of the death penalty. Concluded the Court on this issue:

Thus, while we do not dispute Thompson's testimony that frontal lobe damage can be a cause of mental retardation, Smith has not demonstrated on the facts before us how a current PET scan would be useful in assessing the pivotal question presented in this case-whether his mental functioning was significantly more deficient thirty years ago than today.

Smith, 2008 WL 2721155 , at *4.

See also, Woodall v. Simpson, 2008 WL 5666261, *23 (W.D. Ky. 2008), report and recommendation adopted in part, rejected in part on other grounds, 2009 WL 464939 (W.D. Ky. 2009) (no reasonable necessity for funding to conduct additional neuropsychological testing).

104167 F.3d 1339, 1348-49 (10th Cir.), cert. denied, 528 U.S. 987 (1999).

105 See Allen v. Mullin, 368 F 3d 1220, 1236 ( $10^{\text {th }}$ Cir. 2004) (discussing Walker).

106 Walker, 167 F. 3d at 1348-49.

107620 N.Y.S. 2d 656, 657 (App. Div. 1994).

108 See supra text following note 74 .

109573 F. Supp. 2d 804 (S.D.N.Y. 2008).

$110 \mathrm{Id}$. at 817 . 
what extent will other courts follow this language from Lewis? We simply do not know yet.

3. Will prosecutors seek to introduce such testimony to rebut defendant's Panetti applications?

The administration of antipsychotic medication may have a significant impact on a defendant's neuroimaging results. ${ }^{11}$ Even the boldest commercial technology (the socalled "No Lie MRI") warns of limitations on its valid use in the case of subjects who are "brain damaged".112 Jane Moriarty underscores that such testimony is able to produce "false positives." 113 To what extent will prosecutors introducing such evidence "come clean" and share this information with jurors in cases involving defendants being medicated while on trial or those with brain injuries?

5. To what extent are judges more or less impervious to the "dazzle" or "Christmas tree effect" of such testimony than are jurors?

Steven Erickson writes about the "gloss of intrigue and seduction" inherent in neruoimaging testimony. ${ }^{114}$ Others have noted that the visual "allure"115 of such testimony can "dazzle" and "seduce" jurors" 116 in ways that are "inappropriately persuasive."117 Joelle Moreno says, flatly, "brain research is sexy."118 The vividness of this testimony may have a distortive impact on jurors $j^{119}$ the open question is whether judges are less susceptible than jurors to the vividness heuristic in this setting?

Judges have the same predisposition to uncritically use the vividness heuristic in a variety of other legal settings, whether it be competency to stand trial, the applicability of the Americans with Disabilities Act to persons with mental disability, or dealing with lawyers with mental disability. ${ }^{120}$ Should we have any confidence that they will be immune to its ravages here? ${ }^{121}$

111 See Perlin, supra note 3 , at ${ }^{* *} 33-43$.

112 Reese, supra note 90, at 229. On fMRI tests and lie detection in general, see J.R.H. Law, Cherry-Picking Memories: $f M R I-B a s e d$ Lie Detection in the U.S. Courts, accessible at http://ssrn.com/abstract=1582262.

113 Moriarty, supra note 82, at 48, citing Scott T. Grafton et al, Brain Scans Go Legal, ScIENTIFIC AMERICAN Mind 30, 33 (Dec. 2006/Jan. 2007).

114 Erickson, supra note 23, at 36.

115 Khoshbin \& Khoshbin, supra note 82 , at 182.

116 Id. at 183, 185. See also, Tancredi \& Brodie, supra note 33, at 289; Jennifer Kulynych, Brain, Mind, and Criminal Behavior: Neuroimaging as Scientific Evidence, 36 JuRIMETRICs J. 235, 244 (1996) (all using "seduction" or "seductive" as the descriptor), and An Overview of the Impact of Neuroscience Evidence in Criminal Law (2004) (President's Council on Bioethics Staff Working Paper), available at http:// www.bioethics.gov/ background/neuroscience_evidence.html, at 10 (discussing how jurors can be "dazzled" by MRI displays). 117 Neil Feigenson, Brain Imaging and Courtroom Evidence: On the Admissibility and Persuasiveness of fMRI, 2 INT'L J. L. IN CONTEXT 233, 243 (2006).

118 Joelle Moreno, The Future of Neuroimaged Lie Detection and the Law, 42 Akron L. Rev.717, 734 (2009) (emphasis added).

119 See Perlin, supra note 3, at **12-24.

120 See Michael L. Perlin, "Baby, Look Inside Your Mirror": The Legal Profession's Willful and Sanist Blindness to Lawyers with Mental Disabilities, 69 U. PrTt. L. Rev. 589, 602-03 (2008) (Perlin, "Look Inside Your Mirror') Michael L. Perlin, The ADA and Persons with Mental Disabilities: Can Sanist Attitudes Be Undone?, 8 J. L. \& Health 15, 33 (1993); Michael L. Perlin, Pretexts and Mental Disability Law: The Case of Competency, 47 U. Miami L. Rev. 625, 660 (1993). See supra note 27.

121 Compare Greely, supra note 2, at 1104 n. 7:

This author recently organized a seminar for federal judges on legal issues in genetics and neuroscience. It was striking how uninterested judges were in violence-inducing brain conditions for issues of responsibility, sanity, and so on, and how very interested they were in those same questions in terms of sentencing decisions. Ironically, what might be set out as a mitigating factor for a defendant in terms of responsibility is likely to increase the sentence for a convicted criminal. 


\section{How will such testimony be dealt with if there is a Daubert challenge? .22 $^{122}$}

Scholars have expressed concern that many of the claims made in support of some uses of neuroscience testimony in courts are "wholly unsupportable." "23 Courts have been mixed in their assessment of neroscience evidence under both Frye and Daubert. In at least three instances, Frye jurisdictions have rejected PET scan and SPECT scan evidence, in all cases finding that the evidence in question was not "generally accepted." ${ }^{24}$ In other Daubert cases, though, such evidence has been accepted, albeit in matters involving civil causes of actions. ${ }^{125}$ For the purposes of this article, one of the most intriguing (albeit cryptical) cases is that of Hoskins $v$. State. ${ }^{126}$ There, in a death penalty case, the state Supreme Court vacated the sentence, noting,

Following the PET-scan and the evidentiary hearing, the trial judge concluded that the PET-scan did show an abnormality and that, as conceded by the State, Dr. Krop's testimony changed as a result of the PET-scan. Because the trial judge has found in the affirmative, we vacate the sentence of death imposed on Hoskins and remand this cause for a new penalty phase proceeding. ${ }^{127}$

In a footnote, the court noted that no Frye hearing was held, but added that "The fact that the trial judge did not consider these issues at the evidentiary hearing does not affect our decision to remand this case." 128

What is most critical here is the fundamental unfairness of the Daubert process:

It is obligatory to note the disparity in decisionmaking; that is, that, in Daubert cases, the prosecutor's position is sustained (either in support of questioned expertise or in opposition to it) vastly more often than is that of defense counsel's. ${ }^{129}$ The implications of these findings must be considered as well. ${ }^{130}$

122 See generally Moriarty, supra note 82 ; see supra note 16.

123 Moriarty, supra note 90, at 747. See also, Reese, supra note 90, at 217 (expressing concern that jurors would "overvalue" such evidence).

${ }_{124}$ People v. Protsman, 88 Cal. App. $4^{\text {th }} 509$ (2001); People v. Yum, 111 Cal. App. $4^{\text {th }} 635$ (2003); Clemons v. State, 2003 WL 22047260 (Ala.Crim.App. 2003), rev'd on other grounds, 2007 WL 1300722 (Ala. 2007). See generally, The President's Council on Bioethics, Staff Working Paper: An Overview of Neuroscience Evidence in Criminal Law, accessible at http://www.bioethics.gov/background/neuroscience_evidence/html. Compare Donnellan v. First Student, Inc., 891 N.E. 2d 463 (Ill. App. 2008) (personal injury case) (testimony of expert, who was board certified in nuclear medicine, about the extensive use of Single Photon Emission Computer Tomography (SPECT) scans and detailed explanation about the process of analyzing the scans was sufficient to support the introduction of SPECT evidence) (Frye jurisdiction).

125 See, e.g., Hose v. Chicago Northwestern Transp. Co., 70 F. 3d 968, 973 ( $8^{\text {th }}$ Cir. 1995).

126735 So.2d 1281 (1999).

127 Id. at 1281 .

128 Id. at n. 1 .

129 D. Michael Risinger, Navigating Expert Reliability: Are Criminal Standards of Certainty Being Left on the Dock? 64 ALb. L. REv. 99, 105-08 (2000). In sixty-seven cases of challenged government expertise, the prosecution prevailed in sixty-one of these. Out of fifty-four complaints by criminal defendants that their expertise was improperly excluded, the defendant lost forty-four. Contrarily, in civil cases, ninety percent of Daubert appeals were by the defendants who prevailed two-thirds of the time. For a thoughtful analysis of Professor Risinger's findings, see Deirdre Dwyer, (Why) Are Civil and Criminal Expert Evidence Different?, 43 TULSA L. REV. 381, 382-84 (2007).

Prof. Susan Rozelle is blunter: "The game of scientific evidence looks fixed." Susan Rozelle, Daubert, Schmaubert: Criminal Defendants and the Short End of the Science Stick, 43 Tulsa L. REv. 597, 598 (2007). See also, Erica Beecher-Monas, Reality Bites: The Illusion of Science in Bite-mark Evidence, 30 CARDOzo L. REV. 1369,1371 (2008-2009). On the Daubert problems inherent in cases involving vaccine issues, see Joelle Moreno, It's fust a Shot Away: MMR Vaccines and Autism and the End of the Daubertista Revolution, 35 W. Mitchell L. Rev. 1511 (2009).

${ }_{130}$ Perlin, supra note 3, at 906-07. 
By way of comparison, in a recent critique of how courts treat bite-mark testimony (offered "dressed in the illusion of science"), ${ }^{131}$ Professor Erica Beecher-Monas notes that judges in criminal cases "overwhelmingly circumvent their [Daubert-mandated] gatekeeping responsibilities." 132 Writing about the use of Daubert in vaccine court cases, Professor Joelle Moreno has perceptively noted

Law does not happen in a vacuum. The idea that gatekeeping judges reflect on only the case-specific in-court impact of proffered scientific claims and theories ignores the real world outside the courthouse, the fact that information about science-based legal issues also travels from the bottom-up, and the genuine interdependence of law, science, and society. It is inarguable that judges must focus on the specific facts and issues in each case and the application of proffered scientific evidence to these facts. But, as Justice Breyer observed, this type of perpetual Daubertista focus is an incomplete description of the judicial task because " $[$ ] ]he importance of scientific accuracy in the decision of such [sciencebased] cases reaches well beyond the case itself." 133

Consider also the dangers of teleology in the context of mental disability law jurisprudence: how judges "teleologically... privilege [certain evidence] (where that privileging serves what they perceive as a socially-beneficial value) and subordinate [such evidence] (where that subordination serves what they perceive as a similar value)."134 The post-Daubert caselaw is a textbook example of teleology. This should be a red flag to those who are concerned about the ways in which judges "cherry pick...' social science evidence so as to justify [their] decisions"135 in this area of the law.

6. How will fact-finders deal with such testimony in cases where the evidence revealed by neuroimaging testimony does not comport with their (false) "ordinary common sense" view of "crazy" criminal defendants?"136

One of the prime "sanist myths"137 is the use by jurors of "a fixed vision of popular, concrete, visual images of craziness" in their decisionmaking in cases involving mentally disabled criminal defendants. ${ }^{138}$ Michael Pardo thus states flatly that neuroimaging evidence is significant, in part, because it "provides jurors with information... beyond

131 Beecher-Monas, supra note 129 , at 1369.

132 Id. at 1371 .

133 Moreno, supra note 129, at 1538-39, quoting, in part, Stephen Breyer, Introduction to REFERENCE MANUAL on Scientific Evidence 3 (2d ed. 2000).

134 Perlin, "Look Inside Your Mirror," supra note 120, at 599-600. See also JoHN Q. LA Fond \& MARY L. Durham, Back to the Asylum: The Future of Mental Health Law and Policy in the United States 156 (1992):

"Neoconservative insanity defense and civil commitment reforms value psychiatric expertise when it contributes to the social control function of law and disparage it when it does not. In the criminal justice system, psychiatrists are now viewed skeptically as accomplices of defense lawyers who get criminals "off the hook" of responsibility. In the commitment system, however, they are more confidently seen as therapeutic helpers who get patients "on the hook" of treatment and control. The result will be increased institutionalization of the mentally ill and greater use of psychiatrists and other mental health professionals as powerful agents of social control."

135 Perlin, "Half-Wracked Prejudice," supra note 18, at 29.

136 See Perlin, supra note 17, discussing "ordinary common sense" (OCS).

137 Sanism is an "irrational prejudice of the same quality and character of other irrational prejudices that cause - and are reflected in - prevailing social attitudes of racism, sexism, homophobia, and ethnic bigotry." See e.g., Michael L. Perlin, "And My Best Friend, My Doctor / Won't Even Say What It Is Pve Got": The Role and Significance of Counsel in Right to Refuse Treatment Cases, 42 SAN Diggo L. REv. 735, 750 (2005). On sanism and death penalty decisionmaking, see Michael L. Perlin, The Sanist Lives of furors in Death Penalty Cases: The Puzzling Role of Mitigating Mental Disability Evidence, 8 Notre Dame J. L., Ethics \& Pub. Pol. 239 (1994). On sanism and the reception of and response to neuroimaging evidence, see Perlin, supra note 4.

${ }_{138}$ See, e.g., Perlin, supra note 4, at 900. 
their common-sense background understanding." "139 Joshua Greene and Jonathan Cohen predict that neuroscience evidence will "undermine people's common sense," referring specifically to the public's "libertarian conception of free will and the retributivist thinking that depends on it." 140

Just as false OCS "contaminate[s]" insanity defense practice, ${ }^{141}$ we need to consider how fact-finders may respond to contrary-to-OCS evidence in Panetti cases. Confounding this issue is the research cited by Dr. Dan Martell, showing that jurors are more likely to be convinced by "'bad,' logically irrelevant explanations" for behavior if such explanations are couched in terms of neuroscience."142

In writing about neuroimaging evidence and the insanity defense, this author recently stated

Neuroimaging is (or isn't) hard science. It is (or isn't) relatively easy for jurors to interpret. It is (or isn't) immune to falsification efforts. It is (or isn't) objective. It will (or won't) lead jurors to "better" verdicts in insanity cases. It will (or won't) be used disproportionately in news-friendly cases. It will (or won't) "trump" jurors' inherent suspicion of the insanity defense. It does (and here there is no contradictory or antipodal position) raise a variety of important and provocative legal, behavioral, and social issues, none of which has received nearly enough attention by the courts or by commentators.

So what are we to make of this? I believe that the key to an answer here is a consideration of sanism: to what extent will our prejudices, our stereotypes, our slotting, and our typification overwhelm all other evidence and all other issues in this conversation? In every aspect of mental disability law that I have ever studied, the answer has been "to a great extent." Is there any reason to think it will be less so here? Perhaps the seductive dazzle of colorful pictures will trump millennia of fear and superstition. But, as of today I wouldn't bet on it (and this analysis again completely and consciously sidesteps the question of whether this evidence is as valuable in litigation as its proponents argue). ${ }^{143}$

Is it likely that there will be significant differences in death penalty cases? There is little before us to suggest this.

7. How will the less well-known aspect of Panetti (that which deals with the need for additional expert testimony) be treated in such cases?

There appears to likely be a significant law-practice conflict between the expansive language in Panetti (seeing a broader role for experts), and the reality as to how Ake has been construed in the quarter-century since that case was decided. The issue is especially pressing here, given the potential miscomprehension of neuroimaging

${ }_{139}$ Michael Pardo, Neuroscience Evidence, Legal Culture, and Criminal Procedure, 33 AM. J. CRIM. L. 301,318 (2006).

140 Joshua Greene \& Jonathan Cohen, For the Law, Neuroscience Changes Nothing and Everything, 359 PHIL. Travs. R. Soc. Lond. B. 1775, 1776 (2004) (emphasis added). See also generally, Dean Mobbs et al, Law, Responsibility, and the Brain, 5 PLos Brol. 0693, 0695 (April 2007) (neurosciece may play an "important role" in "updating the intuitions concerning free will and responsibility that may implictly underlie juror deliberations").

141 See Perlin, supra note 17 , at 17.

142 Daniel Martell, Neuroscience and the Law: Philosophical Differences and Practical Constraints, 27 BEHAv. SCI. \& L. 123, 126 (2009), citing D.S. Weisberg et al, The Seductive Allure of Neuroscience Explanations, 20 J. Cognitive Neuroscience 470 (2008).

On the question of the extent to which the use of neuroscience testing (through an fMRI) can teach us about how brain activation is affected when jurors engage in decisionmaking, see Jessica Salerno \& Bette Bottoms, Emotional Evidence and furors' fudgments: The Promise of Neuroscience for Informing Psychology and the Law, 27 BeHAv. ScI. \& L. 273 (2009) (showing how neuroscience can help illuminate certain punitive attitudes of jurors); see also, Joshua Knabb et al, Neuroscience, Moral Reasoning, and the Law, 27 BEHAV. ScI. \& L. 219 (2009) (same).

${ }^{143}$ Perlin, supra note 4, at 915 (footnotes omitted). 
evidence by both judges and jurors, the distortions inherent in the evidence's "Christmas tree effect," and the "stacked deck" Daubert issue. If this aspect of Panetti is ignored, then it appears that the problems alluded to here will only be exacerbated.

In the remand opinion in Panetti, after hearing testimony by expert witnesses, jail guards, other inmates, and jail employees, the trial court found that, notwithstanding Panetti's well-documented and severe mental illness, he did understand the nature of the punishment he would be receiving, and thus was competent to be executed. ${ }^{144}$ This decision was stayed pending appeal, ${ }^{145}$ and as of the time of the submission of this article, there has been no subsequent decision. It is thus not clear at all as to how, on the facts of the case, this will eventually be resolved.

8. What, actually, will neuroimagers do in such cases?

The technology in question seeks to identify brain abnormalities in individuals with serious mental disabilities. ${ }^{146}$ The examining neuropsychologist must review available historical information from the defendant's life history that might potentially point to possible brain impairment (e.g., documented head injuries or other neurological disease processes), or psychiatric disorders that indicate potential chemical and neurotransmitter abnormalities. ${ }^{147}$ Best practices dictate that neuropsychological testing should be employed to to further clarify any neurobehavioral deficits and to pinpoint functional deficits that correlate with behavioral issues related to both the crime and the proposed neuroimaging study. ${ }^{148}$

Whether structural (CT, MRI) or functional (PET, SPECT) approaches are employed will depend on the defendant's mental and neurological history. ${ }^{149}$ Standard protocols typically used would include ensuring an awareness and appreciation of the procedure, potential risks and benefits from the procedure, and the ability to make a decision regarding these issues.

In the case of a defendant alleging incompetency to be executed, this all will be far more challenging. It is an issue that has not been addressed in either the caselaw or the academic literature, ${ }^{150}$ but it is one that inevitably will need to be resolved in the aftermath of Panetti.

\section{CONCLUSION}

There has been an explosion of commentary and academic literature in recent years about the impact of neuroimaging testimony on the criminal trial process. Yet, there has never been any prior consideration of the relationship between this issue and the standards for determining competency to be executed as set out in the Panetti case. The

\footnotetext{
144 Panetti v. Quarterman, 2008 WL 2338498, ${ }^{*} 37$ (W.D. Tex. 2008).

145 Id.

146 See, e.g., Jeremy Blumenthal, Does Mood Influence Moral fudgment? An Empirical Test With Legal And Policy Implications, 29 LAW \& Psychology 1 (2005); Nicole Vincent, Neuroimaging and Responsibility Assessments, Neuroethics (DOI 10.1007/s12152-008-9030-8), downloadable at http://ssrn.com/abstract=1519431.

${ }_{147}$ Perlin \& McClain, supra note 3, manuscript at 18; H.V. Hall \& D. McNinch, Linking Crime-Specific Behavior To Neuropsychological Impairment, 10 IN'TL J. CinN. NeURopsYchol. 113 (1988).

148 Perlin \& McClain, supra note 3; Hall \& McNinch, supra note 147.

149 On the question of informed consent in a neuroimaging context, see Perlin, supra note 3, at **25-36; Greely, supra note 2; Jennifer Kulynych, The Regulation of MR Neuroimaging Research: Disentangling the Gordian Knot, 33 AM. J.L. \& MED. 295 (2007).

${ }_{150}$ This is considered in the broader context of criminal procedure in general in Perlin \& McClain, supra note 3.
} 
issues raised in this article cover a fairly wide range of questions-questions of counsel behavior, juror attitudes, and evidentiary considerations-that, when looked at together, reflect so many of the tensions and ambivalences that are inherent in criminal trials, especially those of death-eligible defendants. ${ }^{151}$

Panetti builds on, clarifies and expands the Ford standard by adding the requirement that the defendant possess a "rational understanding" of the purposes of the forthcoming execution, ${ }^{152}$ but it also enhances the role of expert witnesses at competency-to-be-executed hearings. ${ }^{153} \mathrm{As}$ more and more attention is paid to the role of neuroimaging in the courts, it is inevitable that this testimony will be used (or at least, sought to be used) at such hearings, both by defendants and by prosecutors. We are still faced with the unanswered questions of how judges and jurors will assess such testimony.

The Ford test has, all too often, been no test at all. ${ }^{154}$ Professor Richard Bonnie refers to the "appalling failures" of the criminal justice system that are "amply documented" by Panetti. ${ }^{155}$ In its Panetti decision, the court stressed that, in a case in which a prisoner's mental state "is so distorted by a mental illness" that he does not share with "the community as a whole" an understanding of the concepts of crime and punishment, the objective "of community vindication [is] called in question." 156 For years, scholars have been tentatively exploring the relationship between therapeutic jurisprudence ${ }^{157}$ and its implications for the execution of persons with severe mental disabilities. ${ }^{158}$ Here, the court frontally considers the implications of this dilemma. But it does not-as it was not before it in the Panetti case-consider how neuroscience evidence might be used (or misused) in seeking to resolve these difficult questions.

We are just scratching the surface of the world of neuroscience. The evidence in question is powerful, and may inappropriately affect jurors - and judges -in their decisionmaking in ways that lead "to outcomes that are both factually and legally inaccurate and constitutionally flawed." 159 Self-evidently, in cases involving the death penalty, the risk of error is most troubling and, potentially, the least reversible.

\footnotetext{
151 On the correlation between death-qualification and antipathy toward the insanity defense, see, e.g., Andrea Lyon, But He Doesn't Look Retarded: Capital fury Selection for the Mentally Retarded Client Not Excluded after Atkins v. Virginia, 57 DePaul L. Rev. 701, 712-13 (2008) ("Death-qualified jurors are also much less likely to accept the insanity defense, believing it to be a "loophole allowing too many guilty peopleto go free,"), citing and quoting Phoebe C. Ellsworth et al., The Death-Qualified fury and the Defense of Insanity, 8 LAw \& Hum. Behav. 81, 92 (1984), and Robert Fitzgerald \& Phoebe C. Ellsworth, Due Process vs. Crime Control: Death Qualification and Fury Attitudes, 8 LAw \& HuM. BeHAv. 31, 45 (1984). For more recent confirmatory research, see Brooke Butler \& Adina Wasserman, The Role of Death Qualification in Venirepersons' Attitudes Toward the Insanity Defense, 36 J. ApPL. Soc's Psychology 1744 (2006) (study of 300 venirepersons from a Florida judicial district).

152 Panetti, 128 S. Ct. at 2860.

153 Id. at 2858 .

154 Id.

155 Richard Bonnie, Panetti v. Quarterman: Mental Illness, the Death Penalty, and Human Dignity, 5 OHIO ST. J. CRIM. L. 257, 282 (2007)

156 Panetti, 127 S. Ct. at 2861.

157 See, e.g., Therapeutic Jurisprudence: The Law as a Therapeutic Agent 121, 122 (David Wexler ed. 1990); Essays IN Therapeutic Jurisprudence (David B. Wexler \& Bruce J. Winick eds. 1991); LAW nN A Therapeutic Key: Recent Developments in Therapeutic Jurisprudence (David B. Wexler \& Bruce J. Winick eds. 1996); Therapeutic Jurisprudence Applied: Essays on Mental Health Law (Bruce J. Winick ed. 1997); David B. Wexler, Putting Mental Health Into Mental Health Law: Therapeutic furisprudence, 16 L. \& Hum. Behav. 27 (1992).

${ }_{158}$ See, e.g., Winick, supra note 74 .

159 Perlin, supra note 3 , at ${ }^{*} 47$.
} 
In My Back Pages, Dylan was concerned about "abstract threats" that "deceiv[ed]" his thought processes. ${ }^{160}$ The threats posed here may be far more than abstract ones. Factfinders may think the issues are "quite clear no doubt somehow," but the evidence suggests that they are not.

\section{ACKNOWLEDGMENTS}

The author wishes to thank his research assistants, Cambridge Peters and Naomi Weinstein, for their outstanding work. 